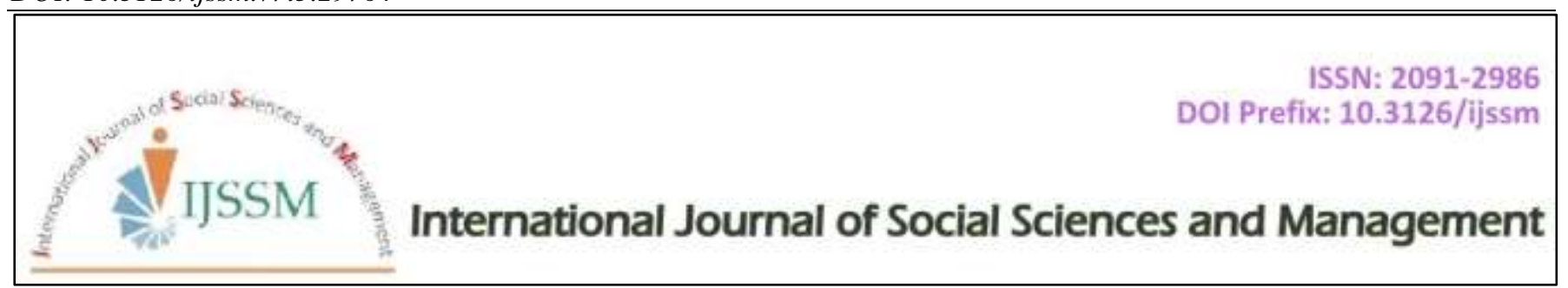

Research Article

\title{
Students' Perceptions of 360 Degree Virtual Tour-Based Historical Learning About the Cultural Heritage Area of the Kapitan and Al-Munawar Villages in Palembang City
}

\author{
Rahman Abidin*, Nunuk Suryani, Sariyatun \\ Historical Education, Sebelas Maret University, Surakarta, Indonesia
}

Article Information
Received: 07 June 2020
Revised version received: 04 July 2020
Accepted: 07 July 2020
Published: 27 July 2020
Cite this article as:
R. Abidin et al. $(2020)$ Int. J. Soc. Sc. Manage. $7(3)$ :
105-112. DOI: $10.3126 / i j s s m . v 7 i 3.29764$
*Corresponding author
Rahman Abidin,
Historical Education, Sebelas Maret University,
Surakarta, Indonesia
Email: rahmanweew @ gmail.com
Peer reviewed under authority of IJSSM
(C) 2020 IJSSM, Permits unrestricted use under the
CC-By-NC license.
OPEN ACCESS
This is an open access article \& it is licensed under a
Creative Commons Attribution Non-Commercial 4.0
International
(https://creativecommons.org/licenses/by-nc/4.0/)

\begin{abstract}
Perception is a process of activities based on one's observations of an object that is observed in the form of responses delivered in oral or written form and can affect the value of an object being observed. Student perception is very important to be known in an assessment. The problem in this study is how students 'perceptions of the 360 Degree Virtual Tour-based Historical Learning about the cultural heritage area of the Kapitan and Al-Munawar villages in Palembang especially the Vocational High School of the Teachers' Association of the Republic of Indonesia 1 Palembang. The purpose of this study was to determine and students' perceptions of 360-degree virtual tour-based history learning about the cultural heritage areas of Kapitan and Al-Munawar villages in Palembang City. The research method used in this research is a descriptive qualitative method. Data collection techniques through interviews, observation, documentation and questionnaires. The Analysis Data Technique uses qualitative descriptive analysis.

From the results of this study obtained data on student perceptions with an average percentage of $87 \%$, seen from the three indicators namely receiving, understanding and assessing or responding to show that students' perceptions of choosing to agree and strongly agree with the excellent category. Thus, the mobile-based history learning model can improve the quality of learning more effectively and easily accepted by students in order to achieve better and more optimal learning outcomes.
\end{abstract}

Keywords: Student Perception, Learning History, Virtual Tour 360, Cultural Heritage Area of Kampung Kapitan and Al-Munawar.

\section{Introduction}

Changes in society that are so fast as a result of progress in science and technology, bringing positive and negative consequences at the same time for life. Sapria (2012:2) revealed until now, the role of educational institutions still remains a hope that can bring enlightenment to people who are experiencing change, but it is also undeniable that educational institutions are always left behind by the progress achieved by the community. As a result, educational institutions need to make adjustments to all developments that occur in the community.

Tirtarahardja (2015:82) states education is universal and continues uninterrupted from generation to generation anywhere in the world. Efforts to humanize humanity through education are carried out in accordance with the 
outlook on life and in the socio-cultural background of each particular society. Therefore, although education is universal, certain differences occur according to the view of life and socio-cultural background. In other words, education is held based on the philosophy of life and based on the socio-cultural of every community, including in Indonesia.

The development of technology has always had a very high role and contributed to the development of the world of education. In the history of educational development, information technology is part of the media used to convey messages of knowledge to many people, starting with printing technology a few centuries ago (Hamzah, 2014: 36). The development of information technology at this time the internet is deploying the history of educational technology on new paths through online services in education both with and without a degree that is basically providing educational services for users by using the internet as a medium (Hamzah, 2014: 37).

Education, especially vocational education, needs to make various changes in the learning process, one of which is by applying different learning concepts. In realizing different learning concepts, of course, requires a change, so that learning objectives can be achieved and learning outcomes increase. Teaching materials are tailored to the needs and interests of students' learning so that it leads to the ability of students to understand learning material quickly and accurately. The role of the internet in education is very beneficial because of its ability to manage data with a very large number (Rusman, 2014:344).

From the explanation above, this study takes a 360-degree virtual tour-based history learning about the cultural heritage area of the village of Kapitan and Al-Munawar in the city of Palembang, which is a collaborative learning activity model using a mobile device (smartphone) so students can digitally tour the cultural heritage area both from school and from home. So in practice, the teacher acts as a facilitator whose job is to help provide experience to students in solving problems related to the subject matter. So in this research, a title was raised "Student Perceptions of Historical Learning Based on 360 Degree Virtual Tour About Kapitan and Al-Munawar Cultural Heritage Areas in Palembang City".

\section{Literature Review}

\section{Perception}

According to Walgito (2010: 99-102), perception is a process that is preceded by a sensing process in which the process of receiving stimulus to individuals through the senses (Sensory Process) from there the process is continued and the next process is a process of perception because the process of perception is not separated from the sensing process. Sensing is the preliminary process of perception the sensing process will take place at any time when the individual receives a stimulus through the senses. According to him, a perception has indicators or stages 1.) Absorbing or accepting the stimulation of objects from outside the individual 2.) Understanding or understanding after the image in the brain is organized so that understanding and understanding are formed 3.) response or evaluation is taken by individuals in various forms, Therefore, perception is individual. According to Rachmat (2003: 51) in the International Journal of Multicultural and Multireligious Understanding Widianingsih (2019: 19) Perception of experience about objects, events or relationships obtained by concluding information and interpreting messages.

According to Sobur (2003: 386-387), perception is a stimulation process with physical responses that can be observed against stimuli. Perception is part of the whole process that produces responses after stimulation is applied to humans. There are 3 main components of the process of perception 1). Selective is the process of filtering by the senses to stimuli from outside 2). Interpretation is the process of organizing information so that it has meaning for someone 3 ). Rounding is a process in the form of behaviour towards the information that arrives.

According to Slameto (2015: 102-104), perception is the process of entry of information into the human brain, through human perception constantly making contact with their environment, so perception is a process in which concerns matters regarding the entry of messages or information into the brain. Through perception, humans will continue to be in contact with their environment. The relationship is carried out through the senses that are owned such as sight, touch, taste, listener, and smell, according to Slameto perception is divided into 3 namely:

1. That perception is relatively human is not a scientific instrument that can absorb everything exactly as it is. With this relativity, the first effect of a stimulus change is felt to be greater than the stimulus that comes later. Based on the fact a teacher can predict the perceptions of students for the next lesson because the teacher already knows the perceptions held by students from previous lessons.

2. The perception is selective that someone only pays attention to just a few stimuli from the many stimuli around him at a particular moment means that the stimulus received depends on what has been learned, this means there are limitations in one's ability to receive stimuli.

3. Perception has the structure of people receiving stimuli not in a careless way. He will accept it in the form of relationships or groups. If the stimulus is incomplete it will complement itself so that the relationship becomes clear. This principle shows that 
the lessons delivered by the teacher must be wellstructured.

4. From the explanation above, the researchers agree with Bimo Walgito that there are 3 perception indicators of perception, namely absorb or accept, understand or comprehend, and respond or assess. The reason researchers used Bimo Walgito's opinion was that the sentence was easier to understand for students or respondents than Slameto and Sobur's opinions.

\section{Historical Learning}

Learning history is a branch of science that examines the origins and development and handling of society in the past that contains wisdom values that can be used to train intelligence, shape the attitudes, character and personality of students (Sapriya, 2012: 209-210). Learning history functions to make students aware of the process of change and development of society in the time dimension and to build historical perspectives and awareness in discovering, understanding, and explaining the national identity in the past, present, and future in the midst of world change (Ministry of National Education, 2003: 6). Historical learning is also a way to shape social attitudes. The social attitudes include mutual respect, respect for differences, tolerance and willingness to live side by side in the nuances of multiculturalism (Susanto, 2014: 62). Learning history has a very important role in shaping the character, attitudes and development of the nation which is meaningful in the formation of an Indonesian nation that has a sense of nationality, intellectual, respecting the struggle of the nation and a sense of nationalism. According to Sapriya (2012: 209) learning history has the following material coverage: (1) contains the values of heroism, example, pioneering, patriotism, nationalism, and unyielding spirit that underlies the process of character formation and personality of students; (2) contains treasures on the civilization of nations including the civilization of the Indonesian people; (3) instil awareness of unity and brotherhood and solidarity to become a unifying nation is facing the threat of disintegration; (4) contains moral teachings and wisdom that are useful in overcoming multidimensional crises faced in everyday life; (5) instil and develop a responsible attitude in maintaining environmental balance and sustainability.

This history learning material is able to develop the potential of students to get to know the values of the nation which were fought for in the past, maintained, and adapted for the present and developed in the future, also in history presented various events and real events that have happened in the past, not only fictional essays, such as the persistence of the fighters against the invaders in maintaining national pride.

\section{Virtual Tour 360}

Virtual tour according to Daud F. (2016) in the journal Bryant (2018: 1) is a technology that puts the user in the picture and allows the user to increase situational awareness as well as increase the viewing power, capture and analyze virtual data significantly. The presentation of the virtual tour uses pictures or videos, in addition, it can use 3D models. A virtual tour is a simulation of an actual location, generally consisting of video sequences or collections of photos (Colasante, 2011). Virtual Tour can also use several other multimedia elements, for examples such as sound effects, music, narration, and text, and is often used to describe varieties of media based on video and photography.

\section{Kapitan and Al-Munawar Cultural Heritage Area}

Poerbantanoe (2001: 43-51) preservation of buildings and / or environment of cultural heritage aims to maintain the authenticity of buildings and / or environment of cultural heritage, protect and maintain buildings and / or environment of cultural heritage from damage, as well as utilize buildings and / or environment culture for the sake of development. Efforts to preserve buildings and / or environmental heritage in Indonesia became an important issue and developed around 1990 in spatial planning in Indonesia. Definition of cultural heritage in the laws of the Republic of Indonesia no. 11 of 2010 contains "cultural preservation is a material cultural heritage in the form of objects, buildings, structures, sites and areas of cultural heritage on land and/or in water that need to be preserved because they have important values for history, religion, education, science, and/or culture through the process of determination". Based on the above definition it can be concluded that the area of cultural preservation is an area that is protected by laws both on land and water which needs to be preserved because it has important value for all fields of science.

\section{Methodology}

To examine the existing problems, researchers need a method that will be used in research in order to achieve the desired goals. The research method can be interpreted as a scientific way to obtain valid data with the aim to be found, developed, and proven, a certain knowledge so that in turn it can be used to understand, solve, and anticipate problems in the field of education (Sugiono, 2012: 6). The method used is qualitative descriptive where this researcher describes the data obtained through a questionnaire that is distributed through percentages. Data collection uses triangulation theory which can be interpreted as a data collection technique that combines various existing data collection techniques and data sources (Table 1). 
Table 1: Instruments

\begin{tabular}{|c|c|c|c|}
\hline Variable & $\begin{array}{l}\text { Criteria for Perception } \\
\text { Indicators }\end{array}$ & Item Question & Information \\
\hline \multirow{3}{*}{$\begin{array}{l}\text { Students' Perceptions of Historical } \\
\text { Learning Based on A } 360 \text { Degree } \\
\text { Virtual Tour About the Cultural } \\
\text { Heritage Area of The Kapitan And Al- } \\
\text { Munawar Villages in Palembang City }\end{array}$} & Receive & $1,2,3,4,5$ & \multirow{3}{*}{$\begin{array}{l}\text { Strongly Agree, } \\
\text { Agree, Disagree, } \\
\text { Strongly Disagree }\end{array}$} \\
\hline & Understand & $6,7,8,9,10$ & \\
\hline & Assess / Response & $11,12,13,14,15$ & \\
\hline
\end{tabular}

Sudijono (2017: 43) The formulas used for the questionnaire are:

$\mathrm{P}=\mathrm{f} / \mathrm{n} \times 100 \%$

Information:

$\mathrm{P}=$ number of percentages achieved

$\mathrm{F}=$ frequency of the number of answers obtained

$\mathrm{N}=$ number of respondents

The results are grouped by percentage by classification according to Ngaliman Purwanto (2010: 82):

$90 \%-100 \%=$ Very good

$80 \%-89 \%=$ Good

$65 \%-79 \%=$ Enough

$55 \%-64 \%=$ Less

\section{Results and Discussion}

This research was conducted to 10th grade students of vocational high school teacher association of the Republic of Indonesia 1 Palembang. After data collection, then the data will be analyzed to find out students' perceptions of learning history based on virtual tours (360 degrees) about the cultural heritage area of the Kapitan and Al-Munawar villages in Palembang City, where the virtual tour contains 360-degree videos. can see in all directions of the area of cultural heritage.

The location of the Kapitan and Al-Munawar villages which is located in the city of Palembang, the Republic of Indonesia is marked in blue, the data is taken from the Jambi Archaeological Heritage Preservation Hall.

The Fig. 1 is a floor plan of the Kapitan House, founded by Tjoa Ham Hin around the year 1850s. Tjoa Ham Hin is an important Chinese figure because of this meritorious in the construction of kapitan homes and homes that are the other. Tjoa Ham Hin holds the position of Kapitan Appointed by the Dutch East Indies government in the 19th century AD appointment of the position of captain of the Chinese for Easy Dutch people in Chinese that time. This arrangement was carried out because of the Chinese people at that time holding the economic or trade sector in Palembang was good in the Palembang Darussalam Sultanate also after the Sultanate was torn down by the Dutch. At the time Furthermore, the position of captain of China can not only be approved Chinese budgets will also be used for Register indigenous people.

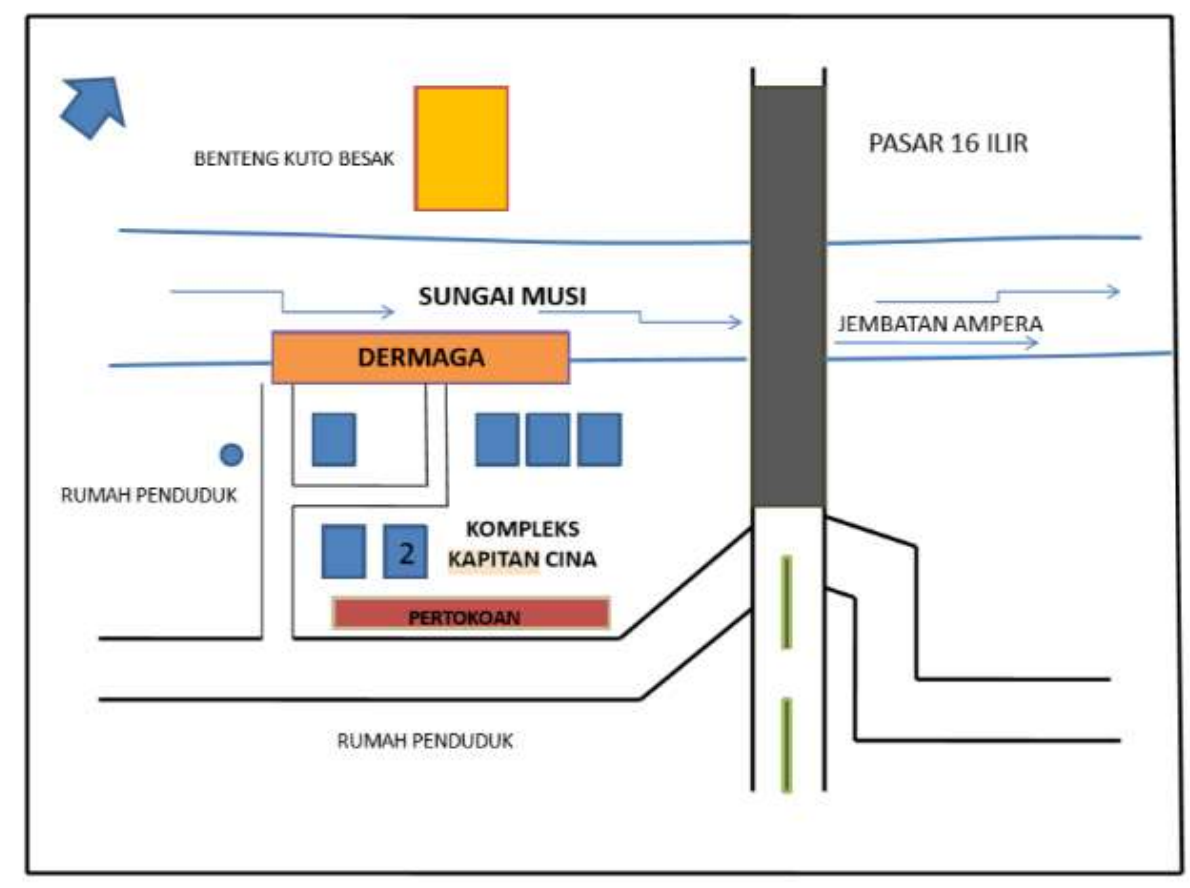

Fig. 1: Village Kapitan

[Source: Dokumen. (2011). Balai Pelestarian Peninggalan Purbakala Jambi.] 


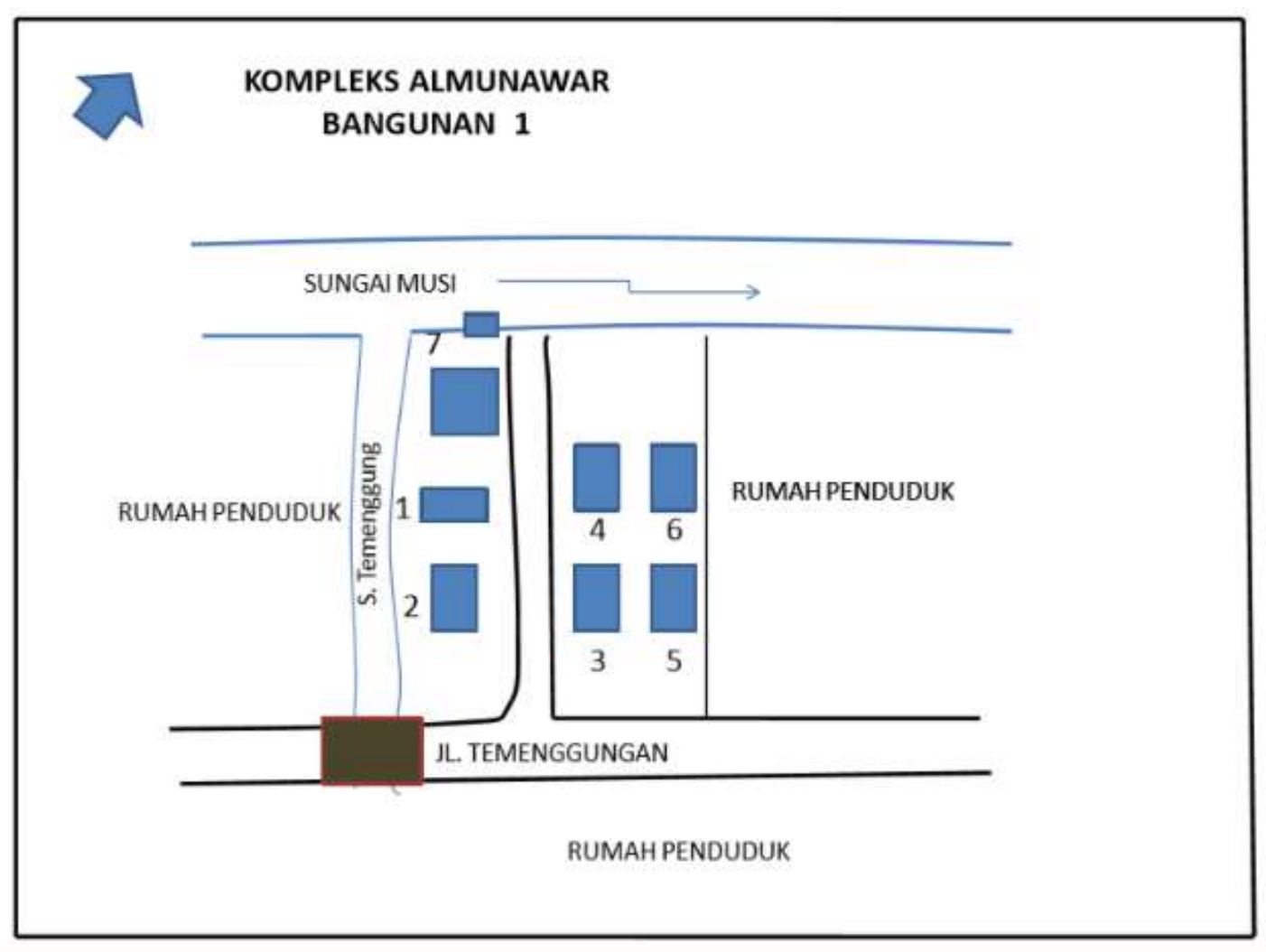

Fig. 2: Village Al-Munawar

[Source: Dokumen. (2011). Balai Pelestarian Peninggalan Purbakala Jambi.]

Based on the Fig. 2, house 1 was the first house built by the founder of the Almunawar site, Al Habib Abdurrahman Almunawar. The establishment of house 1 was estimated at the beginning of the 19th century AD At first the house was inhabited by Al Habib Abdurrahman Almunawar and passed on or bequeathed his first son, namely Al Habib Muhammad. Based on information obtained from interviews, currently, house 1 is inhabited by Mr Salim Abu Bakar Assegaf as well as the owner. Mr Salim Abu Bakar is the fifth generation of the Al Munawar family. House 2 is the second house built after house 1. Establishment of house 2 is estimated in the 19th century AD

Based on the information, currently, house 2 is inhabited by Mr Muhammad. Mr Muhammad is the fifth generation of the Al Munawar family. House 3 was estimated to be built in the 19th century AD They both are the third generation of the Al Munawar family from the founder of his house Hasan Abdurrahman Al Munawar. Based on information on house 4 it is estimated that it was built in the 19th century AD. House 4 is a relic of the Alawiyah Almunawar family. She is the fifth daughter of the founder of the Almunawar site, Habib Abdurrahman bin Muhammad Al Munawar. In the beginning, house 4 functioned as a place to live and now it is transformed into the AlKautsar Islamic Education Foundation school in Palembang. The change occurred in 1986. House 5 is estimated to have been built at the end of the 19th century AD. House 5 is still a legacy from the Almunawar family. Rumah 5 is a legacy from one of the founding children of the Almunawar site, Habib
Abdurrahman bin Muhammad Al Munawar. House 6 is estimated to have been built at the end of the 19th century AD. House 6 is still a legacy from the Almunawar family. Rumah 6 is a legacy from one of the founding daughters of the Almunawar site, Syarifa Ruqoya Al Munawar. At present, the house 6 is inhabited by the family of Syarifa Roquya's heir, Syarifa Muzna. House 7 is estimated to have been built at the end of the 19th century AD. House 7 is still a legacy from the Almunawar family. Rumah 7 is a legacy from one of the daughters of the founder of the Almunawar site, Habiba Syifa.The display is presented in the application which focuses on 360-degree impressions is shown in Fig. 3.

The picture above is the result of the video that was used where the video was taken using a 360-degree camera that was captured / cut in 2 dimensions because the manuscript could not see the picture in 360-degree form, this image was in the location of the village of Kapitan.

After observing and applying the application of history learning by distributing questionnaires to find out the perceptions of 10th grade vocational high school students to 58 students of which the questionnaire was validated by experts.

The results of the questionnaire discussion distributed to respondents based on the selected indicators are explained above, namely receiving, understanding, and evaluating / responding are shown in Fig. $4,5 \& 6$. 
The Fig. 4 shows the indicators received from 5 statements that have been processed to produce data Strongly Agree $35 \%$, Agree 49\%, Disagree 7\% and Strongly Disagree 9\%, then it can be concluded that $84 \%$ stated strongly agree and agree with this students accept the existence of learning history based on virtual tours with $360 \%$ video.

The Fig. 5 shows the indicators received from 5 statements that have been processed to produce data Strongly Agree $35 \%$, Agree 49\%, Disagree 7\% and Strongly Disagree 9\%, then it can be concluded that $84 \%$ stated strongly agree and agree with this students accept the existence of learning history based on virtual tours with $360 \%$ video.

The Fig. 6 shows the indicators assessing/responding to the 5 statements that have been processed produce data that strongly agree $30 \%$, agree $61 \%$, disagree $9 \%$ and strongly disagree $0 \%$, it can be concluded that $91 \%$ states strongly agree and agree with this can be interpreted as an assessment Student responses to learning history based on the virtual tour are very good

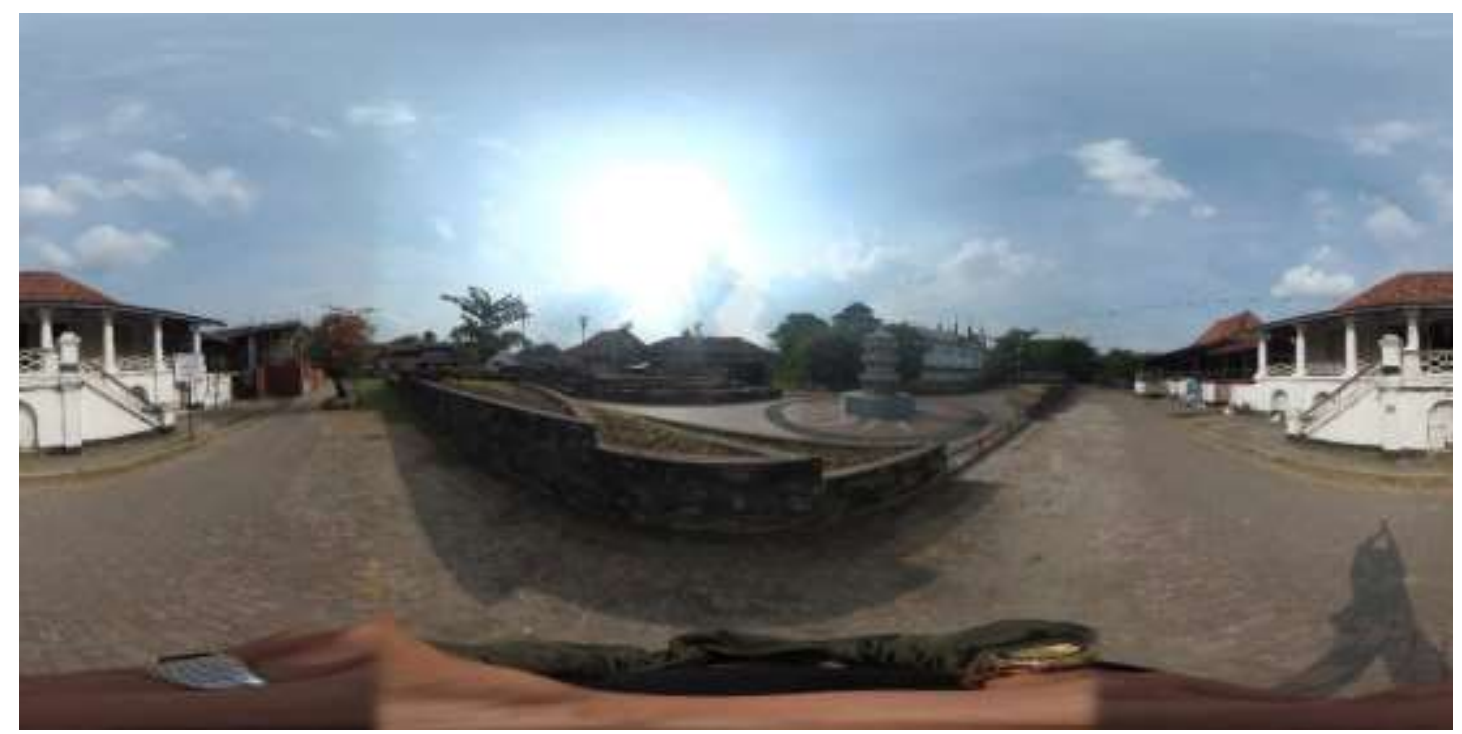

Fig. 3: Example of Capture of 360 Degree Video in Kapitan VillageSource: Personal Data

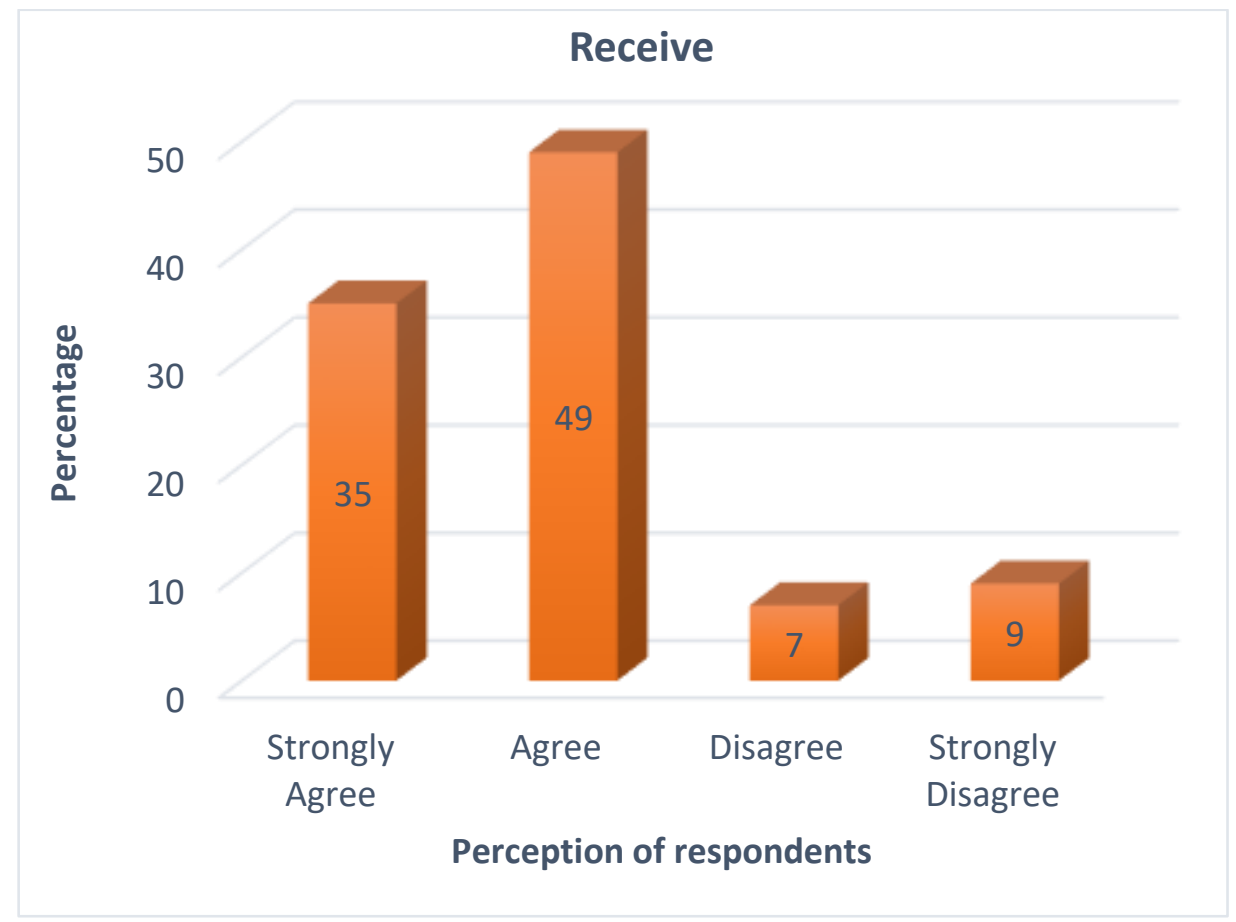

Fig 4: Data showing perception indicator for receiving 


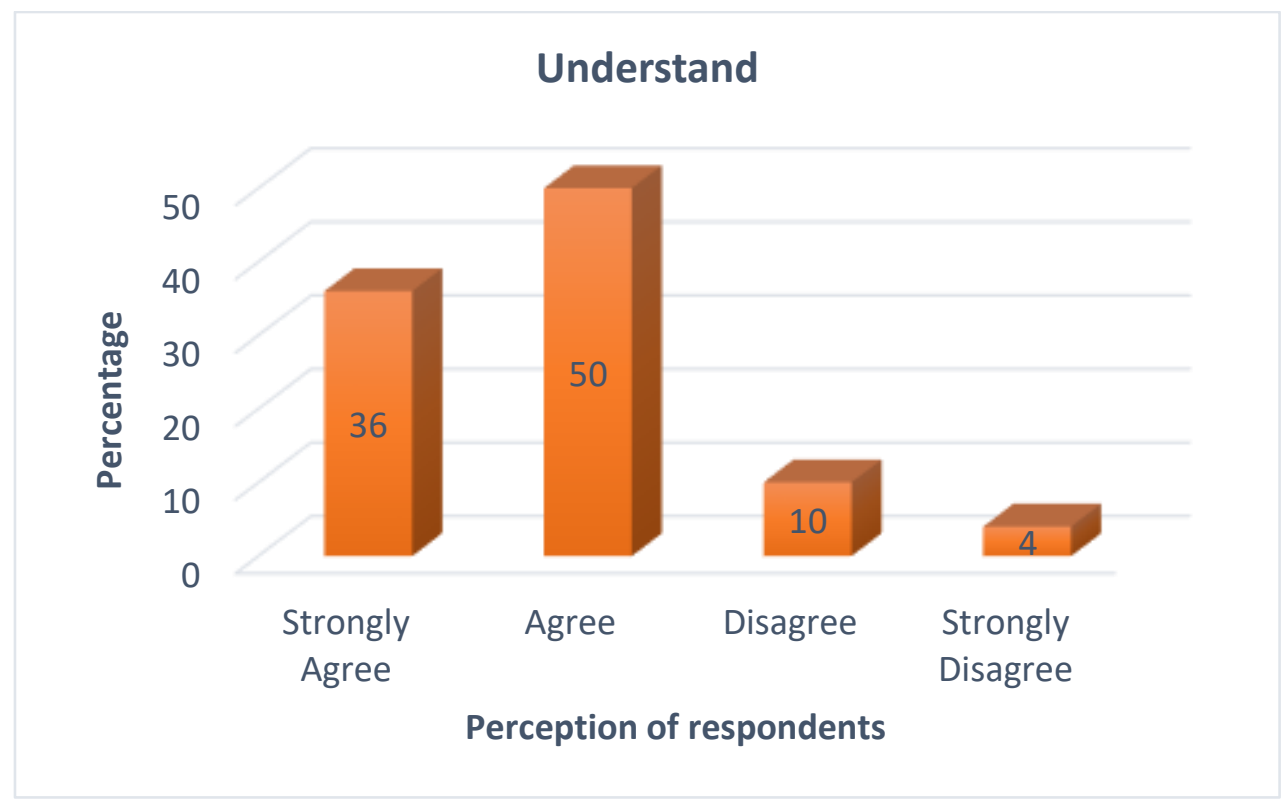

Fig 5: Data showing perception indicator for understanding

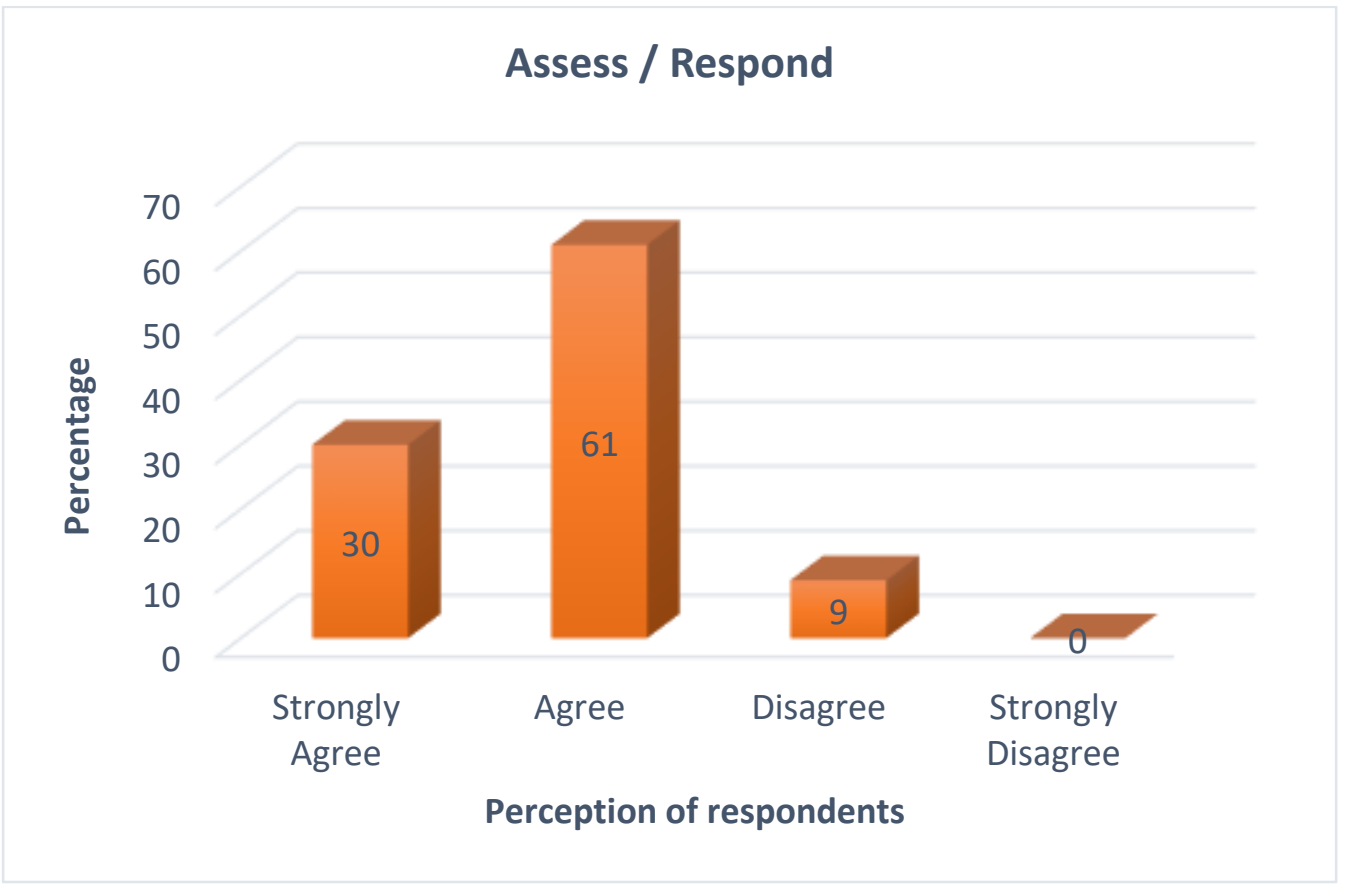

Fig 6: Data showing perception indicator for accessing/responding

From the results shown the Fig. 4-6, it can be discussed students' perceptions of the history of 360-degree virtual tour based on the cultural heritage area of the village of Kapitan and Al-Munawar in the city of Palembang by referring to 3 indicators, namely receiving indicators with $84 \%$ results, indicators understanding with $86 \%$ results, and rate / respond with $91 \%$ results. Then it can be concluded that students' perceptions of the 360 Degree Virtual Tour Based Historical Learning about the cultural heritage area of the Kapitan and Al-Munawar villages in Palembang City the final results obtained with 360 virtual tour-based history learning is an average of $87 \%$ categorized well. As for the supporters of the results of interviews with the teacher Paratiwi,S. E. with several students stated that with this learning more effective and efficient it is easier for teachers and students to see the location of the cultural heritage area and travel as if the viewer was real at the location so that the region does not have to plunge directly into the location .

\section{Conclusion}

Learning the history of students who were previously difficult to get data about the area of cultural ways and can learn directly location very difficult so that students are not able to understand how the situation and conditions of the 
cultural heritage area, especially students are taught by teachers using the lecture method alone, so students have difficulty understanding learning history and become very boring and therefore provide a touch of learning historybased virtual tour that seems to be located in the location of cultural heritage so that teachers and students no longer have trouble finding data and come to the learning areas. With the virtual tour can train students' independence and find something new and can express their opinions to appear brave (active) in the learning process even teachers do not have to bother watching if exploring / tours in cyberspace. Then students can easily (effectively and efficiently) learn to achieve better and more optimal learning outcomes and foster a sense of responsibility to safeguard more cultural heritage.

Students' perceptions of 360-degree virtual tour-based history learning about the cultural heritage area of the Kapitan Dan Al-Munawar village in Palembang City students learn directly as if they were in the location of a cultural heritage area so that teachers and students no longer have trouble finding data and come to the learning areas. With the existence of virtual tour-based history, learning can train students' independence and discover something new and can express their opinions to appear brave (active) in the learning process as well as teachers do not have to bother watching if exploring/tours in the world of time. So, students can easily (effectively and efficiently) learn to achieve better and more optimal learning outcomes and foster a sense of responsibility to safeguard cultural heritage, from using digital virtual tours in 360-degree videos can improve student learning outcomes. proven by student learning outcomes increase.

\section{Conflict of Interest}

Authors declare no any conflict of interest regarding this research work.

\section{References}

Bryant RS and Ngongoloy. (2018) Virtual Tour government agencies of southeast Minahasa Regency. Sam Ratulangi
University Manado. Journal of Informatics Engineering 13(1).

Colasante M (2011) Building Virtual Tour; Considering simulation in the equity of experience concept. In: Ascilite Hobart (Eds) Changing Demands, Changing Directions (pp. 263-268). Ascilite.

Department of National Education. (2003). Curriculum 2004 Special guidelines for the development of syllabus and historical subjects' assessment. Jakarta. Indonesian National Encyclopedias Vol. 6. Jakarta: PT. Cipta Adi Pustaka.

Hamzah (2014) Learning Model. Jakarta: Earth Aksara,

Poerbantanoe B (2001) Partisipasi Masyarakat Didalam Pelestarian Dan Pendokumentasian Warisan (Arsitektur) Kota Surabaya Tahun 1706-1940. DIMENSI. Journal of Architecture and Built Environment 29(1).

Purwanto N (2010) Teaching evaluation. Bandung: PT adolescent Rosdakarya.

Rusman. (2014) Model - Learning model, Jakarta: PT. Raja Grafindo Persada.

Sapriya (2012) Education IPS Concepts and learning. Bandung: PT adolescent Rosdakarya.

Slameto (2015) Learning and influencing factors. Jakarta: Rineka Cipta.

Sobur A (2003) Psikologi Umum. Bandung: CV. Pustaka Setia.

Sudijono A (2017) Introduction to education statistics. Jakarta. PT Raja: Grafindo Persada.

Susanto H (2014) About learning history, issues, ideas and strategies. Yogyakarta: Aswaja Pressindo.

Tirtarahardja U (2015) Introduction to education. Jakarta: Rineka Cipta.

Walgito B (2010) Introduction to General Psychology. Yogyakarta: CV. Andi Offset.

Widianingsih Y (2019) Child's perception in P2TP2A about versioned as a mechanism for resolving a child case with the law conflict. International Journal of Multicultural and Multireligious Understanding 6(10): 12-25. 